\title{
Angiographic characteristics and clinical relations of coronary collaterals in chronic total occlusion lesions
}

\author{
Tomislav Letilović*, \\ Damir Kozmar, \\ Darko Počanić, \\ Mario Stipinović, \\ Maro Dragičević, \\ Vedran Radonić, \\ Helena Jerkić
}

University Hospital "Merkur", Zagreb, Croatia

RECEIVED:

February 3, 2018

ACCEPTED:

February 10, 2018

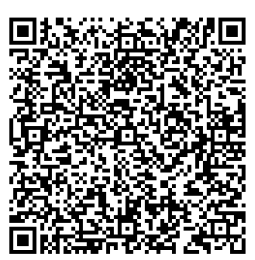

$\square$ Cardiologia Croatica 2018;13(1-2):48.
KEYWORDS: chronic total occlusion, collateral, Werner, Rentrop.

CITATION: Cardiol Croat. 2018;13(1-2):48. | https://doi.org/10.15836/ccar2018.48

*ADDRESS FOR CORRESPONDENCE: Tomislav Letilović, Klinička bolnica Merkur, Zajčeva 19, HR-10000 Zagreb, Croatia. / Phone: +385-98-782-002 / E-mail: tomislavletilovic@gmail.com

ORCID: Tomislav Letilović, https://orcid.org/0000-0003-1229-7983 • Damir Kozmar, https://orcid.org/0000-0001-7626-3534 Darko Počanić, https://orcid.org/0000-0003-3257-110x • Mario Stipinović, https://orcid.org/0000-0002-1582-1552

Maro Dragičević, https://orcid.org/0000-0002-2620-3194 • Vedran Radonić, https://orcid.org/0000-0002-2115-2826 Helena Jerkić, https://orcid.org/0000-0002-1650-4735

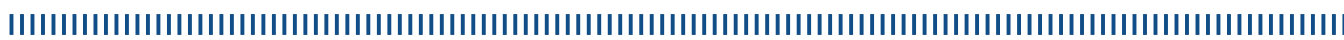

Introduction: Coronary collaterals (CC) are anastomotic connections that can provide an alternative blood supply. They are especially important in the case of the vessel occlusion as they are prerequisite of viability. Collaterals have an indispensable role in any type of chronic total occlusion (CTO) intervention. ${ }^{1}$ Aim of our study was to analyze angiographic characteristics and clinical relations of collaterals in CTO patients.

Patients and Methods: Consecutive patients, in whom at least one attempt of CTO intervention in our institution was attempted, were enrolled. Data from 133 patients were collected from the beginning of the 2015 to the June of 2017. Angiographic characteristics were analyzed using Rentrop and Werner classifications. Possible relation of those angiographic characteristics to coronary risk factors were sought. Association of CC angiographic characteristics and individual components of the so called optimal medical therapy (OMT) was also investigated. 79 (59.4\%) had a CTO of right coronary artery (RCA), 36 (27.1\%) of left anterior descending (LAD) and 18 (13.5\%) of circumflex artery. Mean age was $63.6 \pm 9.2$ years. Mean Rentrop score was $2.1 \pm 0.84$ and mean Werner score was $1.37 \pm 0.51 .99$ patients (74.4\%) had heterocollaterals. Collaterals were frequently (58 patients - $44 \%$ ) of multiple locations i.e. both septal and bridging. Further analyses showed no relation between angiographic characteristics of CC and coronary disease risk factors. No association of any individual component of OMT and CC angiographic characteristics was found. There was a trend of higher Werner class in men as opposed to women ( $1.42 \pm 0.53$ vs $1.25 \pm 0.43 ; \mathrm{p}=0.07$ ).

Conclusion: Our results show that most of the patients have heterocollaterals and frequently from different localizations. We found no connection between angiographic characteristics of CC and coronary disease risk factors as well as medical therapy.

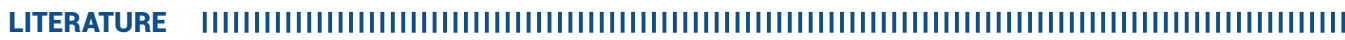

1. Meier P, Schirmer SH, Lansky AJ, Timmis A, Pitt B, Seiler C. The collateral circulation of the heart. BMC Med. 2013 Jun 4;11:143. https://doi.org/10.1186/1741-7015-11-143 